\title{
Hepatocyte growth factor reduces sensitivity to the epidermal growth factor receptor-tyrosine kinase inhibitor, gefitinib, in lung adenocarcinoma cells harboring wild-type EGFR
}

\author{
Hua Yang ${ }^{1,2}$, Rong Wang ${ }^{1}$, Shunli Peng ${ }^{1}$, Longhua Chen ${ }^{1}$, Qi Li ${ }^{3}$, Wei Wang ${ }^{1}$ \\ ${ }^{1}$ Department of Radiation Oncology, Nanfang Hospital, Southern Medical University, Guangzhou, People's Republic of China \\ ${ }^{2}$ Oncology Department, Nanhai Hospital, Southern Medical University, Fuoshan, People's Republic of China \\ ${ }^{3}$ Guangdong Provincial Key Laboratory of Gastroenterology, Department of Gastroenterology, Nanfang Hospital, Southern \\ Medical University, Guangzhou, People's Republic of China
}

Correspondence to: Wei Wang, e-mail: wangwei9500@hotmail.com Qi Li, e-mail: liqi1977@msn.com

Keywords: EGFR-TKI, drug resistance, HGF, lung cancer, wild-type EGFR

Received: September 01, 2015

Accepted: January 31, 2016

Published: February 22, 2016

\section{ABSTRACT}

Epidermal growth factor receptor tyrosine kinase inhibitor (EGFR-TKI) therapy is an option for lung cancers harboring wild-type EGFR when chemotherapeutic reagents have failed. In this study, we found that the EGFR-TKI, gefitinib, modestly suppressed proliferation of the lung cancer cell lines, A549 and H358, which both harbor wild-type EGFR. Treatment with hepatocyte growth factor (HGF) reduced the sensitivity to gefitinib, whereas sensitivity was restored by treatment with an HGF antibody, a MET inhibitor, or depletion of MET but not ErbB3 gene. Moreover, both PI3K/mTOR inhibitors and MEK inhibitors suppressed proliferation of A549 cells, whereas only PI3K/mTOR inhibitors effectively suppressed cell viability of EGFR mutant PC-9 cells. Our findings suggest that HGF reduced the gefitinib sensitivity through MET and downstream PI3K and MAPK pathways. Combined use of EGFR-TKI and MET inhibitors or inhibition of downstream signaling molecules might be a better second or third line choice for a group of patients with advanced lung cancer harboring wild-type EGFR.

\section{INTRODUCTION}

Non-small cell lung cancers (NSCLC) account for about $85 \%$ of lung cancers. Among patients with NSCLC, more than $65 \%$ present with locally advanced or metastatic disease [1]. Unfortunately, less than $15 \%$ of patients with lung cancer survive more than five years. Over the past decade, the identification of specific genetic alterations, such as oncogenic drivers, in lung cancers has lead to a new period of targeted therapy [2]. Targeting oncogenic drivers, such as epidermal growth factor receptor $(E G F R)$ and anaplastic lymphoma kinase $(A L K)$, has brought the most encouraging improvements in lung cancer treatment. Clinical trials of targeted therapy, such as with EGFRtyrosine kinase inhibitor (EGFR-TKI) therapy in EGFR mutant NSCLC and crizotinib therapy in $A L K$ rearranged NSCLC, have demonstrated major improvements in treatment response, quality of life, and progression-free survival compared to chemotherapy [3-5].
EGFR-TKIs, such as erlotinib, gefitinib, and afatinib, are established as initial standard therapies [6-9]. These treatments are particularly effective against NSCLCs harboring activating mutations in EGFR, such as the exon 19 deletion and L858R mutation. Activating mutations in EGFR are observed in up to $50 \%$ of lung adenocarcinomas in Asians and approximately $10 \%$ of Caucasians with NSCLC [10]. Although most patients with EGFR mutations initially respond to TKI therapy, almost all develop acquired resistance. Therefore, in trinsic and acquired resistance have become serious barriers to the outcomes of patients treated with these reagents.

Many of the EGFR-TKI resistant mechanisms have been revealed. Recent studies using new generation EGFR-TKIs show good efficacy in resistant tumors with the EGFR T790M gatekeeper mutation, which accounts for approximately $50 \%$ of resistant tumors [11, 12]. Previously, we have reported that hepatocyte growth factor (HGF), the ligand of the MET receptor, induces resistance 
to gefitinib or new generation EGFR-TKIs in EGFR mutant lung adenocarcinomas through the MET/Gab1/ PI3K/Akt pathway, without involvement of ErbB3 [13, 14], although ErbB3 was critical in MET amplificationinduced gefitinib resistance [15]. We also found that the MET inhibitor, E7050, successfully overcame HGFinduced resistance to EGFR-TKIs [16, 17].

For most patients with advanced lung cancer harboring wild-type $E G F R$, chemotherapy is the prior choice [18]. However, resistance to chemotherapeutic reagents usually develops over time and limits the clinical benefit from chemotherapy. Although the effect of EGFR-TKIs in NSCLC patients with wild-type EGFR remains controversial, some clinical data have shown survival benefit derived from EGFR-TKI treatment for patients previously treated with chemotherapy but still developed disease progression [19-22]. Therefore, several guidelines recommend EGFR-TKIs as an option of second-line treatments for NSCLC patients with wild-type EGFR [23]. Considering the nearly unavoidable resistance to EGFR-TKIs, we propose that a resistance mechanism may also exist in wild-type EGFR lung cancer. If the potential resistance can be identified prior to EGFR-TKI therapy, this specific group of patients may benefit more from EGFR-TKIs.

Since HGF/MET was previously identified as playing a critical role in the resistance mechanism of EGFR-TKIs in EGFR mutant NSCLC, we investigated whether HGF also influenced EGFR-TKI sensitivity in lung adenocarcinoma cells harboring wild-type $E G F R$. We found that HGF significantly reduced sensitivity to gefitinib through the PI3K/Akt and MAPK pathways in lung cancer cells with wild-type EGFR. A MET inhibitor, PHA-665752, completely restored the sensitivity to EGFR-TKI. The results of this study suggest that combined use of EGFR-TKI and MET inhibitors or inhibition of downstream signaling molecules, such as PI3K or MEK, might be a better second or third-line strategy for a group of patients with advanced lung cancer harboring wild-type $E G F R$.

\section{RESULTS}

\section{HGF reduces sensitivity to gefitinib in lung adenocarcinoma cells harboring wild-type $E G F R$}

Gefitinib sensitivity was examined in the lung cancer cell lines, H358 and A549, which express wild-type $E G F R$. Both cell lines express a mutant $K R A S$ gene that is known as a marker of low sensitivity to EGFR inhibition and chemotherapy [24]. As shown in Figure 1A, cell viability of both H358 and A549 cells were modestly inhibited by gefitinib. Treatment with HGF reduced the sensitivity of both cell lines to gefitinib. The effect of HGF was abrogated by pretreatment with an anti-HGF neutralizing antibody but not control IgG (Figure 1B).
In a parallel study, erlotinib suppressed cell viability of H358 cells, but treatment with HGF rescued cells from the effects of erlotinib (Figure 1C). These data indicate that HGF reduced EGFR-TKI sensitivity in lung cancer cells harboring wild-type EGFR.

\section{HGF reduces sensitivity to gefitinib by directly restoring phosphorylation of Akt and ERK1/2}

Next, we explored whether inhibition of MET, the receptor of HGF, could restore the sensitivity to gefitinib in lung cancer cells with wild-type EGFR that were pretreated with HGF. Although the MET inhibitor, PHA-665752, did not affect the growth of H358 or A549 cells at concentrations less than $0.3 \mu \mathrm{mol} / \mathrm{L}$, it restored the sensitivity of cells to gefitinib in a concentration-dependent manner (Figure 2A).

Although both $M E T$ gene amplification and HGF treatment has been shown to induce gefitinib resistance in lung cancers with EGFR mutations, ErbB3 transactivation is involved only in $M E T$ amplification but not in HGF-induced resistance [25]. Therefore, to explore the molecular mechanism by which HGF reduces sensitivity to gefitinib in lung cancer harboring wild-type $E G F R$, we examined the phosphorylation status of MET, EGFR, ErbB3, and the downstream signaling pathways by western blotting. H358 and A549 cells expressed EGFR, ErbB3, and MET proteins, and these molecules were constitutively phosphorylated at various levels. The downstream proteins Akt and ERK1/2 were also phosphorylated. Consistent with the cell viability data, gefitinib successfully inhibited the phosphorylation of EGFR, ErbB3, Akt, and ERK1/2 (Figure 2B). Neither HGF nor PHA-665752 treatment alone affected phosphorylation of EGFR or ErbB3. However, HGF stimulated phosphorylation of MET; MET phosphorylation was inhibited by PHA-665752. Importantly, even in the presence of gefitinib, HGF restored phosphorylation of Akt and ERK1/2, but not EGFR or ErbB3 (Figure 2B). Moreover, the combination of PHA-665752 with gefitinib inhibited MET phosphorylation along with Akt and ERK1/2 phosphorylation. These data indicate that HGF reduced sensitivity to gefitinib by restoring MET-mediated phosphorylation of Akt and ERK1/2 in cells harboring wild-type $E G F R$, consistent with previous data examining $E G F R$ mutant lung cancer cells.

To investigate the relationship between EGFR, MET and ErbB3, we immunoprecipitated MET and examined its correlation with EGFR and ErbB3 in H358 cells. As shown in Figure 2C, MET was not immunoprecipitated with ErbB3, and neither gefitinib nor HGF induced an association of these two molecules. Conversely, MET was constitutively associated with EGFR, and this association was inhibited by gefitinib, suggesting that the association between EGFR and MET may be correlated by EGFR phosphorylation status. Moreover, HGF treatment failed to 
restore the association inhibited by gefitinib (Figure 2C). These results indicate that reduced sensitivity to EGFRTKI with HGF treatment is mediated by the MET signaling pathway but not by ErbB3.

\section{Specific down-regulation of MET, but not ErbB3, restored sensitivity to gefitinib by inhibiting HGF-induced phosphorylation of Akt and ERK1/2}

RNAi was used to determine whether MET was responsible for restoring gefitinib sensitivity. Downregulation of ErbB3 expression by an ErbB3-specific siRNA did not affect either HGF-reduced sensitivity to gefitinib (Figure 3A) or HGF-restored phosphorylation of Akt and ERK1/2 in H358 or A549 cells (Figure 3B). In contrast, down-regulation of MET expression by MET-specific siRNA recovered the sensitivity to gefitinib (Figure 3A), as well as the effect of HGF on the phosphorylation of Akt and ERK1/2 (Figure 3B). These results indicate that $\mathrm{HGF}$ reduces sensitivity to gefitinib in lung cancer cells harboring wild-type EGFR by restoring the Akt signaling pathway via MET phosphorylation, independently of ErbB3.

\section{HGF derived from tumor cells reduces sensitivity to gefitinib in lung adenocarcinoma cells harboring wild-type $E G F R$}

The HGF gene was transfected into lung adenocarcinoma cells. Prior to transfection, H358 and A549 cells secreted undetectable levels of HGF, whereas high levels of HGF were detected in the supernatant of HGF-transfected cells, H358/HGF and A549/HGF (Figure 4A). As expected, H358/HGF cells, but not cells transfected with vector alone (H358/mock), became highly
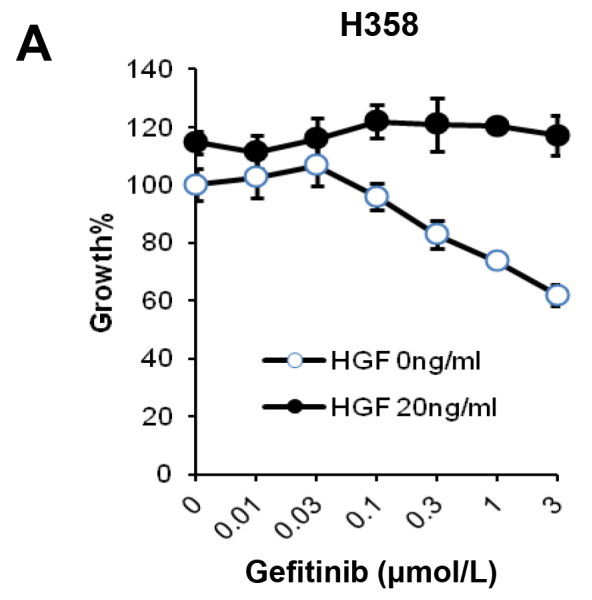

B
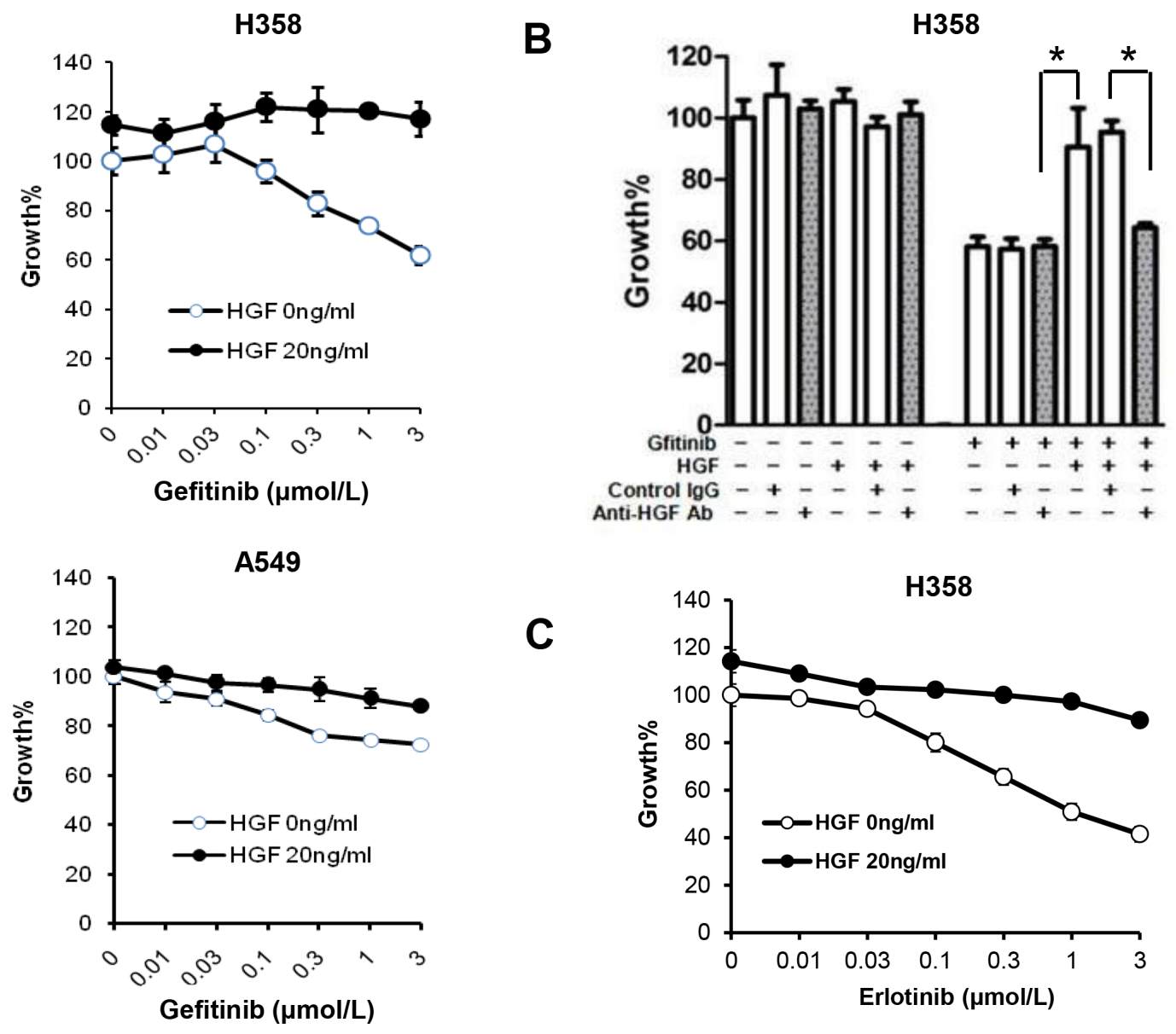

Figure 1: HGF reduces sensitivity to gefitinib in lung adenocarcinoma cells harboring wild-type EGFR. (A) Treatment with HGF reduces sensitivity to gefitinib in wild-type EGFR harboring A549 and H358 cells. Tumor cells were incubated with increasing concentrations of gefitinib and/or HGF, and cell growth was determined after $72 \mathrm{~h}$ of treatment by MTT assay. (B) Pretreatment of HGF with anti-HGF antibody abrogated the HGF-induced resistance of $\mathrm{H} 358$ cells to gefitinib. HGF (20 ng/mL) was pretreated with control $\operatorname{IgG}(2 \mu \mathrm{g} / \mathrm{mL})$ or anti-HGF antibody $(2 \mu \mathrm{g} / \mathrm{mL})$ for $1 \mathrm{~h}$. The resultant solutions were added to the cultures of tumor cells with or without gefitinib $(1 \mu \mathrm{mol} / \mathrm{L})$. Cell growth was determined in the same way as in panel A. ${ }^{*} P<0.01$. (C) HGF reduces sensitivity to erlotinib in H358 cells with wild-type EGFR. Tumor cells were incubated with increasing concentration of gefitinib and/or HGF, and cell growth was determined by MTT assay. 
resistant to gefitinib (Figure 4B). Sensitivity to gefitinib was restored by treatment with PHA-665752 (Figure 4C). These results indicate that tumor cell-derived HGF reduces the sensitivity to gefitinib in lung adenocarcinoma cells harboring wild-type $E G F R$.

\section{Both PI3K/Akt and MAPK signaling pathways are essential to gefitinib resistance in lung cancer cells harboring wild-type $E G F R$}

The PI3K/Akt signaling pathway has been reported as a critical component in the acquired resistance to gefitinib in EGFR mutant NSCLC cells [26-28]. Therefore, we next sought to determine the importance of the PI3K and MAPK downstream signaling pathways in lung cancer cells with mutant or wild-type EGFR using PI3K inhibitors and MEK inhibitors. The PI3K inhibitors, GSK2126458 and PF04691502, strongly inhibited the phosphorylation of Akt. These agents significantly suppressed the proliferation of wild-type EGFR A549 cells and EGFR-mutant PC-9 cells (Figure 5A). The MEK inhibitors,
AZD-8330 and TAK-733, also significantly inhibited the proliferation of A549 cells. However, the inhibitory growth effect of the MEK inhibitors was much less pronounced in PC-9 cells, although phosphorylation levels of ERK1/2 in both cell lines were inhibited (Figure 5B). These results suggested that, in contrast to EGFR mutant lung cancer cells, both PI3K/Akt and MAPK signaling pathways are essential in lung cancer cells with wild-type EGFR.

\section{DISCUSSION}

EGFR inhibitors have been recommended as the first choice for patients with advanced NSCLC that express EGFR activating mutations [29-31]. EGFR inhibitors can also prolong survival in patients with NSCLC after failure of chemotherapy regimens [20]. In the present study, we showed that gefitinib modestly inhibited cell viability of lung cancer cell lines, H358 and A549, through inhibition of EGFR phosphorylation and the downstream signaling molecules, Akt and ERK1/2. However, HGF reduced
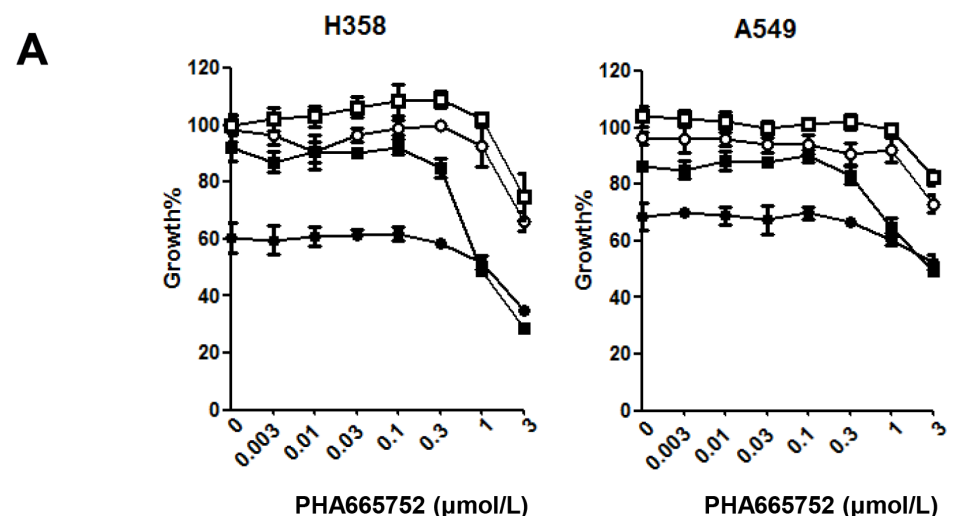

$$
\begin{aligned}
& \text {-o- Control } \\
& \text { - Gefitinb } \\
& \text { - }- \text { HGF } \\
& - \text { Gefitinb+HGF }
\end{aligned}
$$

B
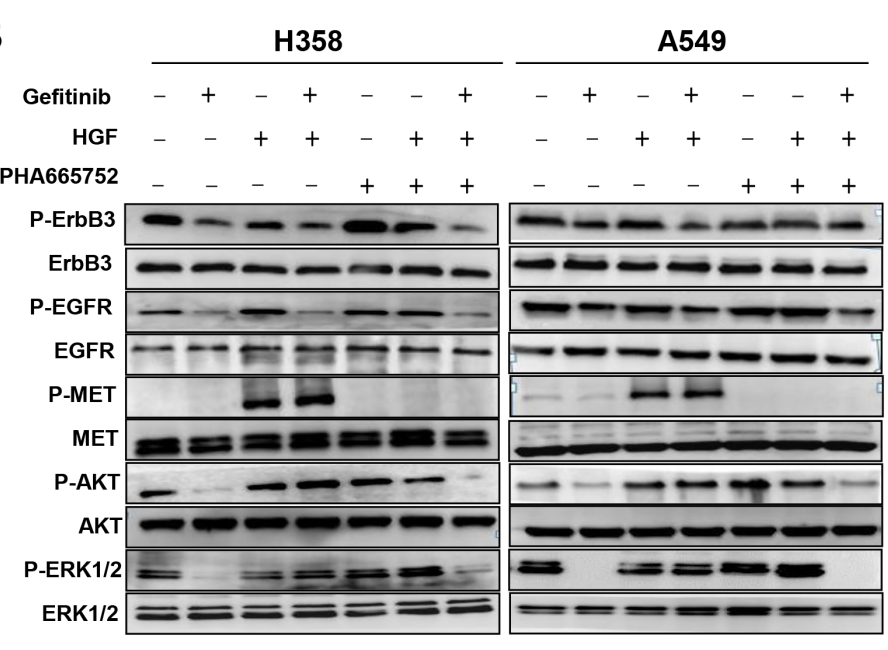

\section{C}

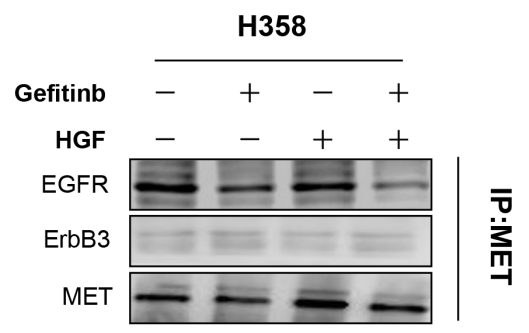

Figure 2: HGF reduces sensitivity to gefitinib by directly restoring the phosphorylation of Akt and ERK1/2. (A) H358 and A549 cells were incubated with various concentrations of PHA-665752, with or without HGF $(20 \mathrm{ng} / \mathrm{mL}) \mathrm{and} / \mathrm{or} \mathrm{gefitinib}(1 \mu \mathrm{mol} / \mathrm{L})$, and cell growth was determined by MTT assay. (B) H358 and A549 cells were incubated with HGF (20 ng/mL), PHA-665752 (1 $\mu$ mol/L), and/or gefitinib $(1 \mu \mathrm{mol} / \mathrm{L})$ for 1 hour. The cell lysates were harvested and phosphorylation of indicated proteins was determined by Western blotting. (C) Cell extracts were immunoprecipitated with an antibody to MET. The precipitated proteins were identified by immunoblotting with the indicated antibodies. 
the sensitivity of these cells to gefitinib. Therefore, the influence of resistant mechanisms to EGFR-TKI sensitivity, such as high HGF levels, should be considered to improve patient prognosis.

$M E T$ amplification has been reported to induce gefitinib resistance via ErbB3 in EGFR mutant lung cancers [15]. However, we and other investigators have demonstrated that HGF induces gefitinib resistance mediated by MET, without the involvement of ErbB3 $[13,25]$. Consistent with previous findings in EGFR mutant NSCLC, we found HGF suppressed sensitivity to gefitinib via the MET pathway without association to ErbB3 in wild-type EGFR NSCLC. Therefore, ligandstimulated MET activation induces different downstream signals to gene amplification-stimulated MET activation in both NSCLCs harboring mutant and wild-type EGFR. The detailed mechanism of this difference needs to be clarified in future studies.

Studies have shown that most lung adenocarcinomas with wild-type $E G F R$ were not highly sensitive to EGFR-TKIs [32-34]. However, even in lung cancer cells with wild-type EGFR, EGFR phosphorylation was inhibited by gefitinib, accompanied by modestly suppression of cell proliferation. Indeed, the firstgeneration of anti-EGFR therapies were all directed against the wild-type receptor [35]. Based on the findings of this study, lung cancers with wild-type EGFR are not addicted to EGFR signal, in contrast to EGFR mutant cells. Thus, at least in a group of lung cancers with wild-type $E G F R$, combining EGFR inhibition with the inhibition of other survival dependent signaling pathways might be a better therapeutic strategy, similar to the successful inhibition of lung cancers with $E G F R$ mutations having acquired resistance [36].

The KRAS mutation has been used as a predictive marker of low sensitivity to EGFR-TKI in lung cancer cells harboring EGFR activating mutations [37]. The mechanism of KRAS mutation related resistance to EGFR-TKI has not been exclusively explained, though many investigators propose that mutant KRAS induces resistance to EGFR-TKI by activating MAPK pathways [38]. In the present study, analysis of A549 and H358 cells, which also express a KRAS mutant, further confirmed this concept. In the experiments of inhibition to downstream signaling pathways, PI3K inhibitors, but not MEK inhibitors, effectively suppressed proliferation of EGFR mutant PC-9 cells. In contrast, both PI3K inhibitors and MEK inhibitors showed inhibitory effects on the proliferation of A549 cells, indicating both downstream signaling pathways are involved in the proliferation of A549 cells.

In the present study, we found that HGF reduced
A

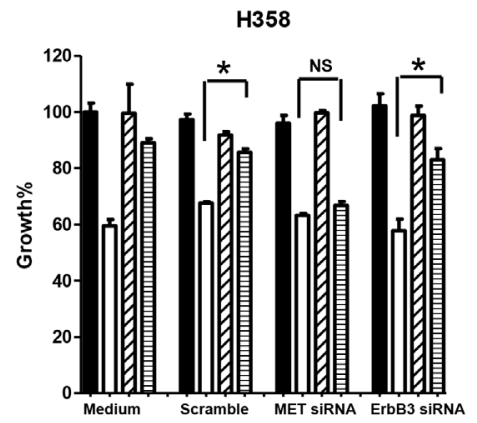

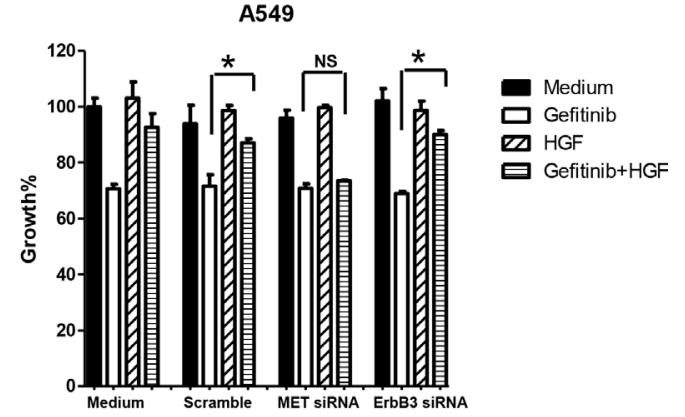

B

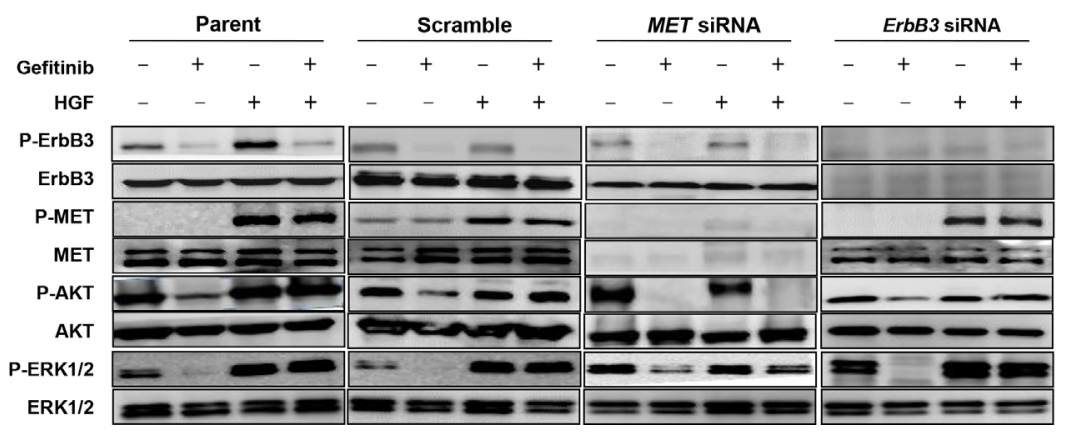

Figure 3: Specific down-regulation of MET, but not ErbB3, restored gefitinib sensitivity by inhibiting HGF inducedphosphorylation of Akt and ERK1/2. (A) MET siRNA, but not ErbB3 siRNA, reversed the enhanced gefitinib resistance with HGF. Cell growth in the presence or absence of gefitinib $(1 \mu \mathrm{mol} / \mathrm{L})$ and/or HGF $(20 \mathrm{ng} / \mathrm{mL})$ was measured by MTT assay. $* P<0.01$. NS: no statistical difference. (B) Down-regulation of MET, but not ErbB3, with specific-siRNAs restored HGF-induced phosphorylation of Akt and ERK1/2 in cells treated with gefitinib. Scramble, MET-specific, or ErbB3-specific siRNAs were introduced into H358 cells. After $48 \mathrm{~h}$, the cells were treated with or without gefitinib $(1 \mu \mathrm{mol} / \mathrm{L})$ and/or HGF $(20 \mathrm{ng} / \mathrm{mL})$ for $1 \mathrm{~h}$, and then cell extracts were prepared and immunoblotted with the indicated antibodies. 
A
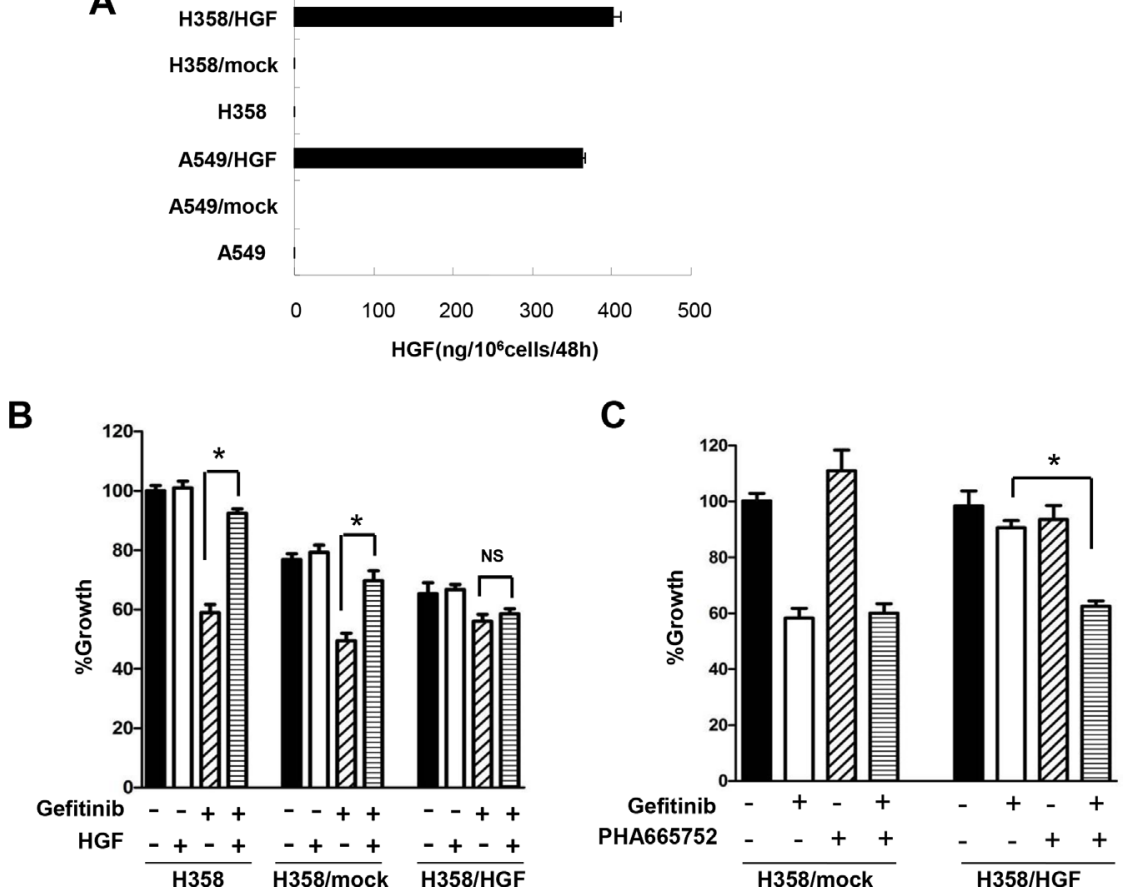

Figure 4: HGF derived from tumor cells reduces sensitivity to gefitinib in lung adenocarcinoma cells harboring wild-type $\boldsymbol{E} \boldsymbol{G F R}$. (A) HGF production by A549, H358, mock-transfected A549 (A549/mock), mock-transfected H358 (H358/mock), $H G F$ gene-transfected A549 (A549/HGF), and HGF gene-transfected H358 (H358/HGF) cells. The cells were incubated in medium for $48 \mathrm{~h}$ and culture supernatants were harvested. The level of HGF in the supernatants was determined by ELISA. (B) $H G F$ gene transfection in H358 cells resulted in resistance to gefitinib. H358, H358/mock, and H358/HGF cells were incubated with or without gefitinib $(1 \mu \mathrm{mol} / \mathrm{L})$ in the presence or absence of HGF $(20 \mathrm{ng} / \mathrm{mL})$. Cell growth was measured by MTT assay. $* P<0.01$. NS: no statistical difference. (C) MET inhibition abrogated endogenous HGF-induced gefitinib resistance. H358/mock and H358/HGF cells were incubated with or without gefitinib $(1 \mu \mathrm{mol} / \mathrm{L})$ in the presence or absence of PHA-665752 $(1 \mu \mathrm{mol} / \mathrm{L})$. Cell growth was measured by MTT assay. ${ }^{*} P<0.01$.
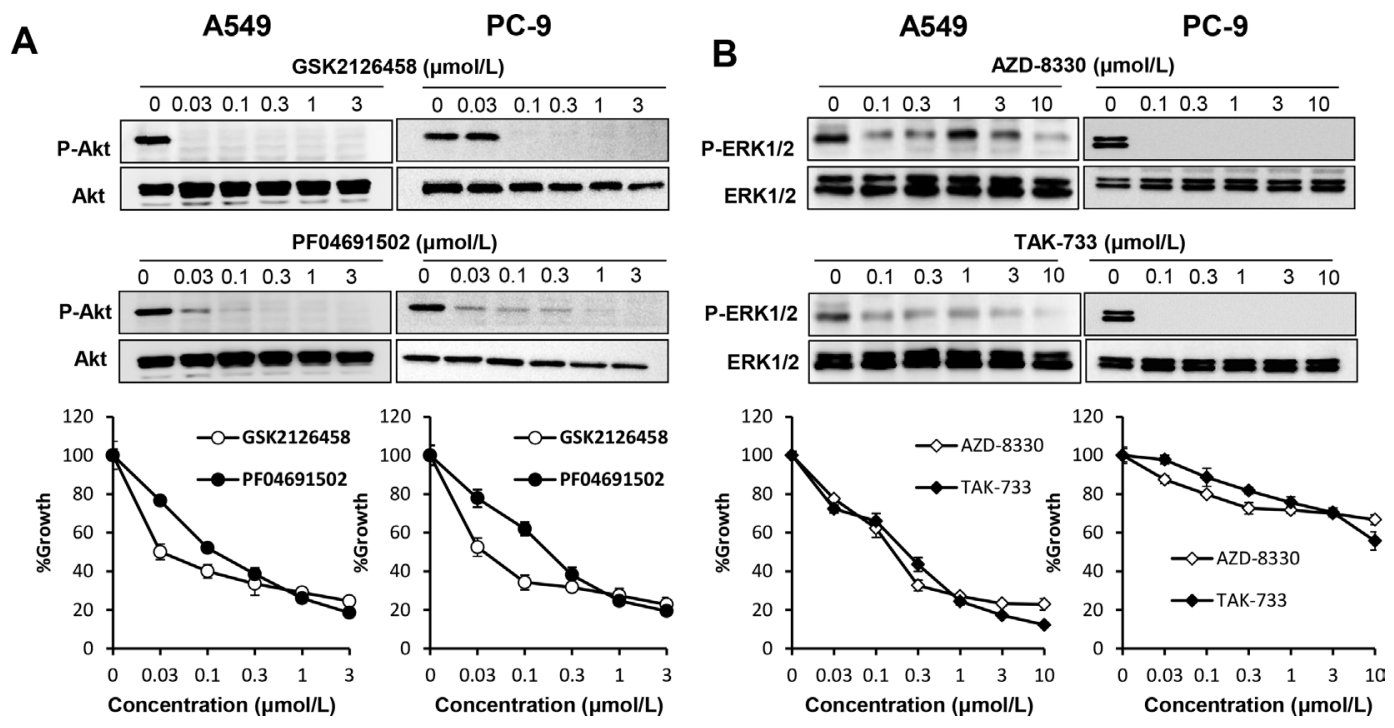

Figure 5: Both PI3K/Akt and MAPK signaling pathways are essential in lung cancer cells harboring wild-type EGFR. (A) PI3K inhibition suppressed proliferation of lung cancer cells harboring mutant or wild-type EGFR. A549 and PC-9 cells were incubated in the presence of various concentrations of GSK2126458 or PF04691502. Cell extracts were prepared after $1 \mathrm{~h}$ of treatment and immunoblotted with the indicated antibodies (upper panel). Cell growth was measured by MTT assay after $72 \mathrm{~h}$ (lower panel). (B) MEK inhibition suppressed proliferation of lung cancer cells harboring mutant or wild-type EGFR. A549 and PC-9 cells were incubated in the presence of various concentrations of AZD-8330 or TAK-733. Cell extracts were prepared after $1 \mathrm{~h}$ of treatment and immunoblotted with the indicated antibodies (upper panel). Cell growth was measured by MTT assay after $72 \mathrm{~h}$ (lower panel). 
the sensitivity to gefitinib, while the MET inhibitor, PHA-665752, restored the sensitivity. MET inhibitors have been researched in many clinical trials [39]. At present, crizotinib, a dual inhibitor of EML4-ALK and MET, already has been widely employed in lung cancer patients harboring the EML4-ALK fusion [40]. Based on our findings, crizotinib might be useful for this group of patients with lung cancers harboring wild-type EGFR. In summary, combined use of EGFR-TKI with a MET inhibitor or inhibition of downstream signaling molecules, such as PI3K or MEK, might be a better therapeutic alternative for at least a part of advanced lung cancer patients.

\section{MATERIALS AND METHODS}

\section{Cell culture and reagents}

The human lung adenocarcinoma cell lines H358 and A549 were purchased from Immuno-Biological Laboratories Co. and American Type Culture Collection, respectively. The human lung adenocarcinoma cell line PC-9 was purchased from Immuno-Biological Laboratories Co. (Gunma, Japan). H358, A549, and PC-9 cell lines were maintained in RPMI 1640 supplemented with $10 \%$ fetal bovine serum (FBS), 100 units $/ \mathrm{mL}$ penicillin, and 100 units/mL streptomycin.

Gefitinib was obtained from AstraZeneca. Goat anti-human HGF neutralizing antibody and control goat IgG were purchased from R \& D Systems. Erlotinib, PHA-665752, GSK2126458, PF04691502, AZD-8330 and TAK-733 were purchased from Selleck chemicals.

\section{Cell proliferation assay}

Cell proliferation was measured using the 3- (4, 5-dimethylthiazol-2-yl)-2,5-diphenyl tetrazolium (MTT) dye reduction method. Tumor cells were plated at a density of $2 \times 10^{3}$ cells $/ 100 \mu \mathrm{L} /$ well into 96 -well plates in RPMI 1640 with 10\% FBS. After 24-h incubation, various concentrations of gefitinib, PHA-665752, and/or HGF were added to each well, and incubation was continued for an additional $72 \mathrm{~h}$. Then, $50 \mu \mathrm{L}$ of MTT solution ( $2 \mathrm{mg} / \mathrm{mL}$; Sigma) were added to all wells, and incubation was continued for another $2 \mathrm{~h}$. The media containing MTT solution was removed, and the precipitated material was dissolved by adding $100 \mu \mathrm{L}$ of DMSO. The absorbance was measured with a microplate reader at test and reference wavelengths of 490 and $570 \mathrm{~nm}$, respectively. The percentage of growth is shown relative to untreated controls.

\section{Antibodies and western blotting}

Western blotting was performed as previously described [41]. The primary antibodies used in this study were anti-Met (25H2), anti-phospho-Met (Y1234/Y1235)
(3D7), anti-phospho EGFR (Y1068), anti-ErbB3 (1B2), anti-phospho-ErbB3 (Tyr1289) (21D3), anti-Akt, or phospho-Akt (Ser473) antibodies (1:1,000 dilution, Cell Signaling Technology), anti-human EGFR (1 $\mu \mathrm{g} / \mathrm{mL})$, anti-human/mouse/rat extracellular signal regulated kinase (ERK)-1/ERK2 $(0.2 \mu \mathrm{g} / \mathrm{mL})$, and anti-phospho ERK1/ERK2 (T202/Y204) $(0.1 \mu \mathrm{g} / \mathrm{mL})$ antibodies (R \& D Systems).

\section{Assay for RNA interference and HGF gene transfection}

Duplexed StealthRNAi (Invitrogen) targeted to MET and ErbB3 and Stealth RNAi Negative Control Low GC Duplex \#3 (Invitrogen) were used for the RNA interference (RNAi) assay. The full-length HGF cDNA was cloned into an expression vector and used for the HGF gene transfection assay. One day before transfection, aliquots of $2 \times 10^{4}$ tumor cells in $400 \mu \mathrm{L}$ of antibiotic-free medium were plated into 24 -well plates. After incubation for $24 \mathrm{~h}$, the cells were transfected with small interfering RNA (siRNA; $50 \mu \mathrm{mol})$ or scramble RNA using Lipofectamine $2000(1 \mu \mathrm{L})$ in accordance with the manufacturer's instructions. After $24 \mathrm{~h}$ incubation, the cells were washed with PBS and plated into 96-well plates. Cell proliferation in the presence or absence of gefitinib (I $\mu \mathrm{mol} / \mathrm{L}$ ) and/or recombinant human $\mathrm{HGF}$ (20 ng/nL) was measured with MTT as previously described. The sequences of siRNAs were as follows: MET, 5'-UCCAGAAGAUCAGUUUCCUAAUUCA-3'; ErbB3, 5' -GGCCAUGAAUGAAUUCUCUACUCUA-3'. Each experiment was done at least in triplicate in three independent experiments.

\section{HGF production}

Cells $\left(2 \times 10^{6}\right)$ were cultured in RPMI 1640 with $10 \%$ FBS for $24 \mathrm{~h}$. The cells were washed with PBS and incubated for $48 \mathrm{~h}$ in RPMI 1640 with 10\% FBS. Then, culture medium was harvested and centrifuged, and the supernatant was stored at $-80^{\circ} \mathrm{C}$ until analysis. To determine the levels of HGF secreted, ELISA was done in accordance with the manufacturer's recommended procedures (Human HGF Quantikine ELISA. R \& D systems). All samples were run in triplicate. Color intensity was measured at $450 \mathrm{~nm}$. Growth factor concentrations were determined by comparison with standard curves. The detection limit was $40 \mathrm{pg} / \mathrm{mL}$.

\section{Statistical analysis}

All data are expressed as the mean \pm SDs of experiments repeated at least three times. Significant differences between the means were measured by a two-tailed unpaired Student $t$ test or one-way ANOVA. $P<0.05$ was considered statistically significant. 


\section{ACKNOWLEDGMENTS}

We thank Central Laboratory of Nanfang Hospital, Southern Medical University for providing technical support.

\section{GRANT SUPPORT}

This work was supported by National Natural Science Foundation of China Grant (81172243 to W. Wang; and 81201961 to Q. Li).

\section{CONFLICTS OF INTEREST}

None.

\section{REFERENCES}

1. Reck M, Heigener DF, Mok T, Soria JC, Rabe KF. Management of non-small-cell lung cancer: recent developments. Lancet. 2013; 382:709-719.

2. Wood SL, Pernemalm M, Crosbie PA, Whetton AD. Molecular histology of lung cancer: from targets to treatments. Cancer Treat Rev. 2015; 41:361-375.

3. Melosky B. Review of EGFR TKIs in Metastatic NSCLC, Including Ongoing Trials. Front Oncol. 2014; 4:244.

4. Duchemann B, Friboulet L, Besse B. Therapeutic management of ALK + nonsmall cell lung cancer patients. Eur Respir J. 2015; 46:230-242.

5. Chan BA, Hughes BG. Targeted therapy for non-small cell lung cancer: current standards and the promise of the future. Transl Lung Cancer Res. 2015; 4:36-54.

6. Khozin S, Blumenthal GM, Jiang X, He K, Boyd K, Murgo A, Justice R, Keegan P, Pazdur R. U.S. Food and Drug Administration approval summary: Erlotinib for the first-line treatment of metastatic non-small cell lung cancer with epidermal growth factor receptor exon 19 deletions or exon 21 (L858R) substitution mutations. Oncologist. 2014; 19:774-779.

7. Fukuoka M, Wu YL, Thongprasert S, Sunpaweravong P, Leong SS, Sriuranpong V, Chao TY, Nakagawa K, Chu DT, Saijo N, Duffield EL, Rukazenkov Y, Speake G, et al. Biomarker analyses and final overall survival results from a phase III, randomized, open-label, first-line study of gefitinib versus carboplatin/paclitaxel in clinically selected patients with advanced non-small-cell lung cancer in Asia (IPASS). J Clin Oncol. 2011; 29:2866-2874.

8. Dungo RT, Keating GM. Afatinib: first global approval. Drugs. 2013; 73:1503-1515.

9. Miller VA, Hirsh V, Cadranel J, Chen YM, Park K, Kim SW, Zhou C, Su WC, Wang M, Sun Y, Heo DS, Crino L, Tan EH, et al. Afatinib versus placebo for patients with advanced, metastatic non-small-cell lung cancer after failure of erlotinib, gefitinib, or both, and one or two lines of chemotherapy (LUX-Lung 1): a phase $2 \mathrm{~b} / 3$ randomised trial. Lancet Oncol. 2012; 13:528-538.

10. Hirsch FR, Bunn PA, Jr. EGFR testing in lung cancer is ready for prime time. Lancet Oncol. 2009; 10:432-433.

11. Kobayashi S, Boggon TJ, Dayaram T, Janne PA, Kocher O, Meyerson M, Johnson BE, Eck MJ, Tenen DG, Halmos B. EGFR mutation and resistance of non-small-cell lung cancer to gefitinib. N Engl J Med. 2005; 352:786-792.

12. Pao W, Miller VA, Politi KA, Riely GJ, Somwar R, Zakowski MF, Kris MG, Varmus H. Acquired resistance of lung adenocarcinomas to gefitinib or erlotinib is associated with a second mutation in the EGFR kinase domain. PLoS Med. 2005; 2:e73.

13. Yano S, Wang W, Li Q, Matsumoto K, Sakurama H, Nakamura T, Ogino H, Kakiuchi S, Hanibuchi M, Nishioka Y, Uehara H, Mitsudomi T, Yatabe Y, et al. Hepatocyte growth factor induces gefitinib resistance of lung adenocarcinoma with epidermal growth factor receptor-activating mutations. Cancer Res. 2008; 68:9479-9487.

14. Wang W, Li Q, Yamada T, Matsumoto K, Matsumoto I, Oda M, Watanabe G, Kayano Y, Nishioka Y, Sone S, Yano S. Crosstalk to stromal fibroblasts induces resistance of lung cancer to epidermal growth factor receptor tyrosine kinase inhibitors. Clin Cancer Res. 2009; 15:6630-6638.

15. Engelman JA, Zejnullahu K, Mitsudomi T, Song Y, Hyland C, Park JO, Lindeman N, Gale CM, Zhao X, Christensen J, Kosaka T, Holmes AJ, Rogers AM, et al. MET amplification leads to gefitinib resistance in lung cancer by activating ERBB3 signaling. Science. 2007; 316:1039-1043.

16. Wang W, Li Q, Takeuchi S, Yamada T, Koizumi H, Nakamura T, Matsumoto K, Mukaida N, Nishioka Y, Sone S, Nakagawa T, Uenaka T, Yano S. Met kinase inhibitor E7050 reverses three different mechanisms of hepatocyte growth factor-induced tyrosine kinase inhibitor resistance in EGFR mutant lung cancer. Clin Cancer Res. 2012; 18:1663-1671.

17. Takeuchi S, Wang W, Li Q, Yamada T, Kita K, Donev IS, Nakamura T, Matsumoto K, Shimizu E, Nishioka Y, Sone S, Nakagawa T, Uenaka T, et al. Dual inhibition of Met kinase and angiogenesis to overcome HGF-induced EGFR-TKI resistance in EGFR mutant lung cancer. Am J Pathol. 2012; 181:1034-1043.

18. Garassino MC, Martelli O, Broggini M, Farina G, Veronese S, Rulli E, Bianchi F, Bettini A, Longo F, Moscetti L, Tomirotti M, Marabese M, Ganzinelli M, et al. Erlotinib versus docetaxel as second-line treatment of patients with advanced non-small-cell lung cancer and wild-type EGFR tumours (TAILOR): a randomised controlled trial. Lancet Oncol. 2013; 14:981-988.

19. Thatcher N, Chang A, Parikh P, Rodrigues Pereira J, Ciuleanu T, von Pawel J, Thongprasert S, Tan EH, Pemberton K, Archer V, Carroll K. Gefitinib plus best supportive care in previously treated patients with refractory advanced non-small-cell lung cancer: results from a randomised, placebo-controlled, multicentre study 
(Iressa Survival Evaluation in Lung Cancer). Lancet. 2005; 366:1527-1537.

20. Shepherd FA, Rodrigues Pereira J, Ciuleanu T, Tan EH, Hirsh V, Thongprasert S, Campos D, Maoleekoonpiroj S, Smylie M, Martins R, van Kooten M, Dediu M, Findlay B, et al. Erlotinib in previously treated non-small-cell lung cancer. N Engl J Med. 2005; 353:123-132.

21. Gregorc V, Novello S, Lazzari C, Barni S, Aieta M, Mencoboni M, Grossi F, De Pas T, de Marinis F, Bearz A, Floriani I, Torri V, Bulotta A, et al. Predictive value of a proteomic signature in patients with non-small-cell lung cancer treated with second-line erlotinib or chemotherapy (PROSE): a biomarker-stratified, randomised phase 3 trial. Lancet Oncol. 2014; 15:713-721.

22. Jazieh AR, Al Sudairy R, Abu-Shraie N, Al Suwairi W, Ferwana M, Murad MH. Erlotinib in wild type epidermal growth factor receptor non-small cell lung cancer: A systematic review. Ann Thorac Med. 2013; 8:204-208.

23. Ettinger DS, Akerley W, Bepler G, Blum MG, Chang A, Cheney RT, Chirieac LR, D'Amico TA, Demmy TL, Ganti AK, Govindan R, Grannis FW Jr, Jahan T, et al. Non-small cell lung cancer. J Natl Compr Canc Netw. 2010; 8:740-801.

24. Roberts PJ, Stinchcombe TE. KRAS mutation: should we test for it, and does it matter? J Clin Oncol. 2013; 31: 1112-1121.

25. Turke AB, Zejnullahu K, Wu YL, Song Y, Dias-Santagata D, Lifshits E, Toschi L, Rogers A, Mok T, Sequist L, Lindeman NI, Murphy C, Akhavanfard S, et al. Preexistence and clonal selection of MET amplification in EGFR mutant NSCLC. Cancer Cell. 2010; 17:77-88.

26. Engelman JA, Janne PA, Mermel C, Pearlberg J, Mukohara T, Fleet C, Cichowski K, Johnson BE, Cantley LC. ErbB-3 mediates phosphoinositide 3-kinase activity in gefitinibsensitive non-small cell lung cancer cell lines. Proc Natl Acad Sci U S A. 2005; 102:3788-3793.

27. Donev IS, Wang W, Yamada T, Li Q, Takeuchi S, Matsumoto K, Yamori T, Nishioka Y, Sone S, Yano S. Transient PI3K inhibition induces apoptosis and overcomes HGF-mediated resistance to EGFR-TKIs in EGFR mutant lung cancer. Clin Cancer Res. 2011; 17:2260-2269.

28. Xie M, He J, He C, Wei S. gamma Secretase inhibitor BMS-708163 reverses resistance to EGFR inhibitor via the PI3K/Akt pathway in lung cancer. J Cell Biochem. 2015; 116:1019-1027.

29. Rosell R, Carcereny E, Gervais R, Vergnenegre A, Massuti B, Felip E, Palmero R, Garcia-Gomez R, Pallares C, Sanchez JM, Porta R, Cobo M, Garrido P, et al. Erlotinib versus standard chemotherapy as first-line treatment for European patients with advanced EGFR mutation-positive non-small-cell lung cancer (EURTAC): a multicentre, open-label, randomised phase 3 trial. Lancet Oncol. 2012; 13:239-246.

30. Zhou C, Wu YL, Chen G, Feng J, Liu XQ, Wang C, Zhang S, Wang J, Zhou S, Ren S, Lu S, Zhang L, Hu C, et al.
Erlotinib versus chemotherapy as first-line treatment for patients with advanced EGFR mutation-positive non-small-cell lung cancer (OPTIMAL, CTONG-0802): a multicentre, open-label, randomised, phase 3 study. Lancet Oncol. 2011; 12:735-742.

31. Mitsudomi T, Morita S, Yatabe Y, Negoro S, Okamoto I, Tsurutani J, Seto T, Satouchi M, Tada H, Hirashima T, Asami K, Katakami N, Takada M, et al. Gefitinib versus cisplatin plus docetaxel in patients with non-small-cell lung cancer harbouring mutations of the epidermal growth factor receptor (WJTOG3405): an open label, randomised phase 3 trial. Lancet Oncol. 2010; 11:121-128.

32. Sharma SV, Haber DA, Settleman J. Cell line-based platforms to evaluate the therapeutic efficacy of candidate anticancer agents. Nat Rev Cancer. 2010; 10:241-253.

33. Cappuzzo F, Hirsch FR, Rossi E, Bartolini S, Ceresoli GL, Bemis L, Haney J, Witta S, Danenberg K, Domenichini I, Ludovini V, Magrini E, Gregorc V, et al. Epidermal growth factor receptor gene and protein and gefitinib sensitivity in non-small-cell lung cancer. J Natl Cancer Inst. 2005; 97:643-655.

34. Pao W, Miller V, Zakowski M, Doherty J, Politi K, Sarkaria I, Singh B, Heelan R, Rusch V, Fulton L, Mardis E, Kupfer D, Wilson R, et al. EGF receptor gene mutations are common in lung cancers from "never smokers" and are associated with sensitivity of tumors to gefitinib and erlotinib. Proc Natl Acad Sci U S A. 2004; 101:13306-13311.

35. Pao W, Chmielecki J. Rational, biologically based treatment of EGFR-mutant non-small-cell lung cancer. Nat Rev Cancer. 2010; 10:760-774.

36. Stewart EL, Tan SZ, Liu G, Tsao MS. Known and putative mechanisms of resistance to EGFR targeted therapies in NSCLC patients with EGFR mutations-a review. Transl Lung Cancer Res. 2015; 4:67-81.

37. Timar J. The clinical relevance of KRAS gene mutation in non-small-cell lung cancer. Curr Opin Oncol. 2014; 26:138-144.

38. Stinchcombe TE. Novel agents in development for advanced non-small cell lung cancer. Ther Adv Med Oncol. 2014; 6:240-253.

39. Gozdzik-Spychalska J, Szyszka-Barth K, Spychalski L, Ramlau K, Wojtowicz J, Batura-Gabryel H, Ramlau R. C-MET inhibitors in the treatment of lung cancer. Curr Treat Options Oncol. 2014; 15:670-682.

40. Shaw AT, Ou SH, Bang YJ, Camidge DR, Solomon BJ, Salgia R, Riely GJ, Varella-Garcia M, Shapiro GI, Costa DB, Doebele RC, Le LP, Zheng Z, et al. Crizotinib in ROS1rearranged non-small-cell lung cancer. N Engl J Med. 2014; 371:1963-1971.

41. Liu T, Sun Q, Li Q, Yang H, Zhang Y, Wang R, Lin X, Xiao D, Yuan Y, Chen L, Wang W. Dual PI3K/mTOR inhibitors, GSK2126458 and PKI-587, suppress tumor progression and increase radiosensitivity in nasopharyngeal carcinoma. Mol Cancer Ther. 2015; 14:429-439. 